\title{
Mechanizmy działania strefy euro a uwarunkowania wybuchu kryzysu finansowego w strefie
}

\begin{abstract}
Wstęp
Konsekwencje kryzysu gospodarczego i finansowego, który wybuchł w Europie w 2008 roku, nadal wywierają negatywny wpływ na europejską gospodarkę. Wzrost gospodarczy w strefie euro pozostaje na poziomie niższym od oczekiwanego, mimo działań podejmowanych zarówno na poziomie ponadnarodowym - przez instytucje Unii Europejskiej, jak i krajowym - przez rządy państw członkowskich. Przyczyn obecnej sytuacji gospodarczej strefy euro należy jednak poszukiwać nie tylko wśród czynników stricte ekonomicznych. Jest to jeden z powodów, dla których działania podejmowane na płaszczyźnie ekonomicznej nie przynoszą spodziewanych rezultatów, a przyszłość europejskiej integracji zaczyna być postrzegana coraz mniej optymistycznie, także przez tzw. „euroentuzjastów”.

Celem artykułu jest charakterystyka i analiza mechanizmów działania strefy euro, które przyczyniły się do wybuchu kryzysu w strefie. Szczególna uwaga zostanie poświęcona kwestii swobody przepływu kapitału w kontekście prowadzonej przez EBC jednolitej polityki pieniężnej i braku wspólnej polityki fiskalnej.
\end{abstract}

\section{Mechanizmy dzialania strefy euro}

Budowa unii gospodarczej i walutowej (UGW) w ramach Unii Europejskiej, przypieczętowana postanowieniami traktatu z Maastricht, stanowiła ukoronowanie wieloletnich wysiłków państw członkowskich, najpierw Europejskiej Wspólnoty Gospodarczej (EWG), a następnie Unii Europejskiej (UE), ukierunkowanych na zacieśnienie i pogłębienie integracji gospodarczej na kontynencie europejskim. Warto podkreślić, choć nie jest to przedmiotem rozważań w niniejszym artykule, że UGW była i jest projektem nie tylko gospodarczym, ale także politycznym i społecznym. Dwa ostatnie aspekty procesu integracji nie były nadto szeroko dyskutowane podczas wdrażania Planu Delorsa (por. Delors, 1989). Wynikało to prawdopodobnie z przyjęcia optymistycznego założenia, że na przestrzeni lat (od 1958 roku) kraje Unii Europejskiej wypracowały już model współpracy na płaszczyźnie politycznej, zaś ich społeczeństwa wykształciły poczucie ponadnarodowej wspólnoty i tożsamości europejskiej.

Proces budowy UGW, a szczególnie strefy euro, został szeroko opisany w literaturze przedmiotu (por. np. European Commission, 1990; Molle, 2000; de Grauwe, 2003; Gawlikowska-Hueckel, Zielińska-Głębocka, 2004; Raport NBP, 2014; Bilski, 2006; 
Bukowski, 2007). Z punktu widzenia celu artykułu zasadne wydaje się jednak wskazanie kluczowych rozwiązań, które zostały przyjęte przy konstruowaniu strefy euro, ponieważ stanowią one główną przyczynę nie tyle samego kryzysu w strefie (kryzysy są zjawiskami naturalnymi i nieuchronnymi), co jego zasięgu, głębokości i czasu trwania. Chciałabym jednocześnie podkreślić, co już wcześniej czyniłam (Bilski, Janicka, 2015), że nie zgadzam się ze swoistym relatywizowaniem zjawiska kryzysu w strefie euro poprzez zastępowanie go pojęciem „kryzysu w niektórych krajach strefy euro”. Nie można, w zależności od okoliczności, postrzegać strefy euro jako zintegrowanego organizmu ${ }^{1}$, bądź jako grupy niezależnych krajów ${ }^{2}$. Jeśli członkostwo w strefie euro pozbawia władze krajów członkowskich kluczowych narzędzi polityki gospodarczej, sytuacja gospodarcza poszczególnych krajów staje się pochodną funkcjonowania strefy jako całości, a nie tylko ich własnych decyzji ekonomicznych. Strefa euro jest obecnie nazywana „niedokończoną integracją”, jej konstrukcja podlega surowej krytyce. Co zdumiewa najbardziej, przed wybuchem kryzysu mechanizmy działania strefy euro nie były postrzegane jako potencjalne źródło zaburzeń jej sprawnego funkcjonowania. Tymczasem już wówczas można było przewidzieć, że taka częściowo zintegrowana struktura może napotkać na istotne ograniczenia stabilnego działania w przyszłości.

Przechodząc do konkretów - za kluczowe fundamenty ekonomiczne, na których zbudowano strefę euro, można uznać następujące:

- przeniesienie na poziom ponadnarodowy polityki pieniężnej i kursowej;

- rezygnacja z walut narodowych, wprowadzenie jednej waluty - euro;

- pozostawienie na poziomie krajowym polityki fiskalnej (teoretycznie), brak prawdziwie wspólnego budżetu.

Na poziomie krajowym pozostawiono najbardziej newralgiczną, z punktu widzenia politycznego i społecznego, politykę, czyli politykę fiskalną̧ ${ }^{3}$. Nie podjęto również decyzji o stworzeniu prawdziwie wspólnotowego budżetu, który umożliwiałby dystrybucję środków finansowych między krajami osiągającymi nadwyżki finansowe a tymi, które nie są w stanie ich wypracować. Gotowość krajów do przystąpienia do strefy euro oceniana była i jest w oparciu o tzw. kryteria konwergencji nominalnej i realnej. Wśród kryteriów konwergencji nominalnej występują kryteria monetarne (dotyczące kształtowania się inflacji i stopy procentowej - de facto oprocentowania dziesięcioletnich obligacji skarbowych), fiskalne (dotyczące poziomu deficytu budżetowego i zadłużenia publicznego - swoboda kształtowania polityki fiskalnej na poziomie krajowym jest więc mocno ograniczona) oraz kursowe (dotyczące stabilności waluty krajowej). Konwergencja realna wyznaczana jest zwykle w oparciu o synchronizację cykli koniunkturalnych, która jest istotna z punktu widzenia jednolitej polityki pieniężnej. Czy są jednak badane wskaźniki odzwierciedlające zdolność kraju do konkurowania na wspólnym rynku? Zauważmy, że w procedurze akcesyjnej nie jest w ogóle badana struktura gospodarki i zdolność do uzyskiwania przez kraj przewagi

${ }^{1} \mathrm{~Np}$. nie ma statystyk dotyczących przepływów finansowych między krajami strefy euro, są one traktowane jako przepływy wewnątrzstrefowe, a nie międzynarodowe.

${ }^{2}$ Poprzez postrzeganie kryzysu jako problemu wybranych krajów strefy euro, a nie całej strefy.

${ }^{3}$ Konieczność powołania w strefie euro unii fiskalnej wskazana została przez M. D. Bordo, A. Markiewicza, L. Jonunga, por. M. D. Bordo, A. Markiewicz, L. Jonung, Fiscal Union for the Euro: Some Lessons from History, NBER Working Paper no. 17380/2011. 
konkurencyjnej na rynkach zagranicznych. Trudno oczekiwać, by kraje, które dotąd nie wypracowały odpowiedniej pozycji konkurencyjnej na rynkach zagranicznych nagle, tylko za sprawą uczestnictwa w obszarze jednowalutowym, przebudowały swoje gospodarki w kierunku wzmocnienia pozycji eksportowej. Tym bardziej, że poziom ich rozwoju gospodarczego i innowacyjności może istotnie różnić się od pozostałych krajów należących do obszaru. Taka sytuacja wystąpiła właśnie w strefie euro - z jednej strony kraje tzw. Południa (Grecja, Włochy, Hiszpania, Portugalia), z drugiej kraje Północy (Niemcy, Holandia, Belgia, Luksemburg, Finlandia).

\section{Kryzysogenne uwarunkowania dzialania strefy euro}

Centralizacja polityki pieniężnej i wprowadzenie wspólnej waluty pozbawiły kraje członkowskie strefy euro kluczowych narzędzi polityki gospodarczej (m.in. zarządzania poziomem stopy procentowej i dostosowawczych zmian kursu waluty krajowej) nie dając nic w zamian. Banki centralne krajów strefy euro przestały pełnić bardzo ważną funkcję, niedocenianą w czasach ekonomicznej prosperity, kluczową w okresie kryzysu - pożyczkodawcy ostatniej instancji. Bank centralny w sytuacji zagrożenia destabilizacją sektora bankowego, a przez to całego systemu finansowego, będącą rezultatem niedostatecznej płynności sektora, zapewnia instytucjom kredytowym dostęp do środków finansowych. W strefie euro ponadnarodowy bank centralny (Europejski Bank Centralny) nie został w tę funkcję wyposażony. Uwzględniając fakt, że krajowe banki centralne zostały jej pozbawione, w strefie euro w ogóle nie przewidziano istnienia instytucji pożyczkodawcy ostatniej instancji. Można z tego wnioskować, że konstruktorzy strefy euro założyli, iż europejski sektor bankowy jest uodporniony na kryzys płynności. Założenie to było o tyle optymistyczne, iż w strefie euro, przy pogłębiającej się integracji rynku kredytowego i rosnącej skali transgranicznego zaangażowania instytucji kredytowych, nie stworzono także rzeczywistego ponadnarodowego nadzoru nad europejskim rynkiem finansowym, w tym rynkiem bankowym. Powód tego stanu rzeczy jest niestety bardzo prozaiczny - kraje członkowskie UE nie wyraziły zgody, głównie ze względów politycznych, na przeniesienie nadzoru nad rynkiem finansowym na poziom ponadnarodowy i tym samym na utratę kontroli nad jego funkcjonowaniem. Sytuację na rynku finansowym cechowała więc znacząca asymetria - pogłębianiu integracji rynku kredytowego nie towarzyszyło symetryczne pogłębianie integracji instytucjonalnej odnośnie do nadzoru (por. Janicka, 2015b, s. 116-130). Obecnie UE wdraża projekt budowy unii bankowej, która teoretycznie ma zlikwidować wspomnianą asymetrię (Geeroms, Karbownik, 2014). Uwzględniając jednak fakt, że pierwotne zasady działania unii bankowej są stopniowo zmieniane w efekcie braku zgody państw członkowskich na część wypracowanych rozwiązań, ostateczny kształt unii bankowej różni się od pierwotnych propozycji (Sicilia i in., 2013). Nie zlikwidowano także problemu braku pożyczkodawcy ostatniej instancji, który objawił się z całą mocą w momencie wybuchu w strefie euro kryzysu bankowego. Z uwagi na przyjęte rozwiązania prawne, EBC nie mógł pełnić tej funkcji, częściowo ma być ona zastąpiona właśnie przez powstanie unii bankowej (i przyjęte rozwiązania odnośnie do dokapitalizowywania instytucji kredytowych), częściowo zaś przez utworzenie Euro- 
pejskiego Mechanizmu Stabilności (który ma także dostarczać środków finansowych, pod postacią pożyczek, rządom krajów strefy euro pogrążonym w problemach finansowych) (por. Zielińska, 2016).

Uważam, że przyjęte rozwiązania nie oznaczają istotnej zmiany jakościowej na europejskim rynku finansowym, a stanowią jedynie doraźny środek zapobiegawczy. Trudno uznać za rozwiązanie systemowe specyficzny mechanizm uporządkowanej likwidacji banków będący częścią unii bankowej (tzw. resolution), czy też powołanie funduszu, który tworzą składki krajów członkowskich strefy euro (szerzej o EMS: Trzcińska, 2013). Rozwiązanie systemowe powinno być nie tylko uniwersalne i skuteczne, ale przede wszystkim „neutralne” dla krajów członkowskich. Jest rzeczą wysoce niepożądaną, aby kraje korzystające z pomocy finansowej z EMS były pod presją krajów dobrze prosperujących gospodarczo i były piętnowane jako te, które sobie nie radzą. Takie rozwiązanie nie tylko nie sprzyja europejskiej integracji, ale wręcz działa jej wbrew poprzez tworzenie napięć o charakterze społecznym i politycznym między krajami będącymi biorcami netto i dawcami netto środków finansowych do funduszu, zwanego nie wiedzieć czemu „mechanizmem”. Udzielenie pożyczki przez EMS jest uwarunkowane przyjęciem przez kraj strefy euro rygorystycznego planu reform gospodarczych, podobnie jak w przypadku pożyczek udzielanych przez Międzynarodowy Fundusz Walutowy, o żadnym automatycznie działającym mechanizmie wspomagającym przywracanie stabilności gospodarczej nie może być w tym wypadku mowy.

W tej sytuacji powstaje pytanie, dlaczego, mimo mankamentów konstrukcji strefy euro, kraje były tak bardzo zainteresowane przystąpieniem do niej, że niektóre z nich gotowe były sfałszować wartości wskaźników makroekonomicznych, aby się w niej znaleźć (Grecja, Włochy). Analiza najczęściej wymienianych w opracowaniach kosztów i korzyści (np. European Commission, 1990; Meltzer, 1996; Zika, 2006; Majone, 2012; Beetsma, Giuliodori, 2010) wiążących się z przystąpieniem do strefy euro nie uzasadnia takiej determinacji. $Z$ jednej strony rezygnacja $z$ krajowej polityki pieniężnej i własnej waluty, z drugiej - brak kosztów wymiany walut i ryzyka walutowego (w przypadku transakcji zawieranych w euro), czy też porównywalność cen i ułatwienie przepływu inwestycji. Nawet pobieżne porównanie kosztów i korzyści jasno wskazuje, że są one wysoce asymetryczne. Nie można zestawiać ze sobą konsekwencji utraty istotnej części suwerenności w polityce gospodarczej i kosztów wymiany walut, bądź braku ryzyka walutowego! To są kategorie nieporównywalne, o zupełnie innym ciężarze gatunkowym. W takim razie, jeśli oficjalnie wymieniane koszty faktycznie znacząco przeważały korzyści, jaki był kluczowy argument przyświecający państwom UE tworzącym strefę euro? Uważam, że należy za takowy uznać rozumiane w szerokim zakresie poczucie bezpieczeństwa, przede wszystkim w aspekcie ekonomicznym. Przynależność do strefy euro, szczególnie w przypadku państw słabiej rozwiniętych, takich jak Grecja, Hiszpania czy Portugalia, oznaczała stanie się częścią dużej, stabilnej struktury gospodarczej, zaś scedowanie istotnej części prerogatyw w zakresie prowadzenia polityki gospodarczej na organy ponadnarodowe częściowo zwalniało państwa (w ich odczuciu) z odpowiedzialności za stan gospodarek krajowych. Na ile to poczucie okazało się złudne dowiódł wybuch kryzysu, kiedy to nagle teoretycznie zintegrowana strefa euro stała się w praktyce grupą państw posługujących się wspólną walutą. Jednocześnie należy dodać, że skutki kryzysu były zróżnicowane w poszcze- 
gólnych krajach strefy - kraje tzw. Północy, a szczególnie Niemcy, wyszły z niego bez większych konsekwencji.

Pozbawione kluczowych narzędzi oddziaływania na gospodarkę, pogrążone w kryzysie kraje zostały pozostawione same sobie i zmuszone do wprowadzenia drastycznych programów oszczędnościowych, które spowodowały pogłębienie na ich rynkach zapaści gospodarczej. W momencie wybuchu kryzysu ujawniła się także pozorna niezależność polityki fiskalnej prowadzonej na poziomie krajowym, jako że wymogi dotyczące wielkości deficytu budżetowego i zadłużenia publicznego uczyniły narzędzia polityki fiskalnej mało możliwymi do zastosowania. Powrót przez kraje do ograniczeń w przepływach kapitału oraz swobody zarządzania stopą procentową na rynku krajowym nie był możliwy. Najciężej dotknięte przez kryzys kraje znalazły się w sytuacji patowej (por. de Grauwe, 2013).

\section{Swoboda przeplywu kapitału w strefie euro}

Jak wspomniałam, w strefie euro nie tylko zlikwidowano bariery w swobodnym przepływie środków finansowych (szerzej: Janicka, 2010, s. 241-261) i zakazano na mocy prawa możliwości ich przywrócenia (podobnie jak w całej UE), ale także zlikwidowano publicznie dostępne statystyki obrazujące skalę przepływów finansowych między krajami strefy euro, postrzegając te przepływy jako „wewnątrzstrefowe”. Jeśli przyjąć, że strefa euro nie jest jednak, z punktu widzenia gospodarki, jednolitą całością, taki zabieg jest zupełnie niezrozumiały. Ekonomiści i kraje strefy euro nie mają bowiem w tej sytuacji przejrzystych danych wskazujących na skalę ich wzajemnego zadłużenia, jedyne dostępne dane dotyczą kształtowania się salda rachunku obrotów bieżących odzwierciedlającego współcześnie nie tyle skalę nierównowagi handlowej", co różnicę między oszczędnościami i inwestycjami w danej gospodarce. Jest więc rzeczą oczywistą, że kraje o wysokiej ujemnej wartości salda bilansu obrotów bieżących były i są krajami o pogłębiającej się nierównowadze zewnętrznej wiążącej się z nadmiernym uzależnieniem od finansowania zewnętrznego. Kluczowe w tym wypadku jest właśnie pojęcie „finansowanie zewnętrzne”. Czy oznacza ono napływ kapitału z krajów strefy euro, a więc przepływy wewnątrzstrefowe, nieujmowane w oficjalnych statystykach, czy napływ kapitału spoza strefy euro, który w tej sytuacji utożsamiany jest wprost z zadłużeniem zagranicznym? Biorąc pod uwagę fakt, że przepływy wewnątrzstrefowe klasyfikowane były w inny sposób niż przepływy międzynarodowe, zadłużenie krajów strefy euro $w$ innych krajach członkowskich nie było postrzegane jako powód do niepokoju. Przed wybuchem kryzysu kształtowanie się salda rachunku obrotów bieżących poszczególnych krajów członkowskich nie było w ogóle przedmiotem badań, kluczowe były wartości odzwierciedlające poziom równowagi całej strefy euro, a te nie dawały powodów do podjęcia działań korygujących. Tymczasem nawet pobieżna analiza wartości sald rachunku obrotów bieżących krajów członkowskich wyraźnie wskazuje, że nierównowaga wewnątrz strefy euro pogłębiała się

${ }^{4}$ Stosowane przez teorię ekonomii uproszczenie sprowadzające wartość salda rachunku obrotów bieżących do salda obrotów handlowych staje się współcześnie bezużyteczne z uwagi na rosnący udział salda przepływu dochodów z inwestycji. 
- z jednej strony kraje Południa charakteryzujące się znaczącym deficytem na rachunku obrotów bieżących, z drugiej - kraje Północy wykazujące nadwyżki (por. Janicka, 2015a, s. 99-111). Jeśli strefa euro byłaby rzeczywiście, na wzór struktur państwa, zintegrowanym organizmem gospodarczym, przepływy finansowe od ośrodków nadwyżkowych do deficytowych, odzwierciedlające m.in. różnicę w poziomach ich konkurencyjności, byłyby rzeczą normalną. W każdym kraju istnieją regiony o znaczeniu kluczowym, które generują relatywnie wysokie dochody i regiony peryferyjne, do których transmitowane są (zwykle bezzwrotne) środki finansowe. Skala nierówności jest różna w poszczególnych państwach, ale trudno wyobrazić sobie gospodarkę krajową, której wszystkie regiony osiągają ten sam poziom rozwoju społeczno-gospodarczego, postrzegany zwykle poprzez uniwersalny, choć nieprecyzyjny, miernik, za jaki można uznać kształtowanie się PKB per capita.

Strefa euro jest często porównywana do Stanów Zjednoczonych Ameryki Północnej. Warto w takim razie wskazać, że między stanami USA mają miejsce znaczące transfery finansowe, które umożliwiają spójne funkcjonowanie całej zróżnicowanej struktury, jaka składa się na ten kraj (The Economist, 2011). Znaczącej niezależności na poziomie stanowym towarzyszy zintegrowana struktura federalna odpowiedzialna za prowadzenie polityki pieniężnej, kursowej i fiskalnej, dysponująca rzeczywistym budżetem oraz bankiem centralnym pełniącym funkcję pożyczkodawcy ostatniej instancji. Stany „nadwyżkowe” solidarnie dzielą się środkami finansowymi ze stanami „deficytowymi” nie przez żadne mechanizmy czy fundusze, a poprzez zwyczajny budżet. W UE rozwiązanie takie na razie nie jest rozważane. Okazało się, że lata wielowymiarowego pogłębiania integracji nie doprowadziły do wykształcenia europejskiej tożsamości i europejskiej solidarności. Europa zawiodła w momencie próby, za jaki można uznać wybuch kryzysu. Jeśli nie czujemy się Europejczykami, a definiujemy się tylko poprzez przynależność narodową, po co budować strefę euro, uczestnictwo w której niesie ze sobą istotne zagrożenia dla słabszych gospodarczo państw peryferyjnych? Nie jest możliwe, by wszystkie kraje strefy euro osiągnęły poziom rozwoju społeczno-gospodarczego Niemiec czy Holandii. Składają się na to czynniki nie tylko ekonomiczne, ale także polityczne, kulturowe i społeczne.

Kraje strefy euro, także w sytuacji kryzysowej, nie mogą powrócić do ograniczania swobody przepływu kapitału. Rzecz logiczna w sytuacji pełnej integracji gospodarczej i walutowej, jednak nielogiczna w sytuacji wybuchu kryzysu w jednym z krajów strefy euro, który właśnie się dowiedział, że z kryzysem musi radzić sobie sam, nie dysponując de facto żadnym narzędziem polityki gospodarczej.

\section{Kryzys w strefie euro - przypadek Grecji}

Na temat kryzysu w Grecji powstało wiele opracowań (np. Petrakos, 2014; Bilski, Janicka, 2015; Couretas, Vlamis, 2010, s. 391-404; Arghyrou, Tsoukalas, 2010). Celem artykułu nie jest dyskusja dotycząca uwarunkowań wybuchu tego kryzysu, a jedynie pokazanie mechanizmów, które stały się przyczyną jego ogromnej skali. Warto bowiem podkreślić, że należy rozróżnić te dwie kwestie: czynniki, które doprowadziły 
do wybuchu kryzysu per se oraz czynniki, które wpłynęły na możliwość ograniczenia jego zasięgu i głębokości. O ile nie sposób zdjąć z władz greckich odpowiedzialności za sam wybuch kryzysu, co do tego nie mam wątpliwości, o tyle niemożność skorzystania przez nie z narzędzi polityki makroekonomicznej, tj. czasowe przywrócenie ograniczeń dotyczących swobody przepływu kapitału, które zapobiegłoby m.in. wydrenowaniu greckiego sektora bankowego z funduszy, czy też możliwość odejścia od jednolitej polityki pieniężnej, która stała się kompletnie nieadekwatna do sytuacji greckiej gospodarki, przyczyniła się znacząco do jego porażającej skali. Kluczowy jest szczególnie pierwszy z wspomnianych aspektów, czyli czasowe przywrócenie kontroli przepływu kapitału, które zapobiegłoby nie tyle ucieczce kapitału zagranicznego, co kapitału krajowego, masowo wywożonego z Grecji za granicę przez jej własnych obywateli. Rodzi się pytanie - jeśli pogrążony w kryzysie kraj nie może próbować ustabilizować sytuacji gospodarczej przez zatrzymanie na rynku kapitału krajowego, podniesienie stóp procentowych, które byłyby adekwatne do wzrostu ryzyka inwestycyjnego ${ }^{5}$, zwiększenie wydatków budżetowych w celu stymulowania popytu (bo ma już nadmierny deficyt), to jakie środki pozostają do jego dyspozycji? W rezultacie transfer środków finansowych do greckiej gospodarki służy nie tyle jej stabilizacji i rozwojowi, co zapobiega jej całkowitemu załamaniu. Nie jest to jednak droga wyjścia z kryzysu.

W 2015 roku wspólnie z J. Bilskim przeprowadziliśmy analizę przypadku Grecji i konkluzja naszych rozważań była następująca: uważamy, że główną przyczyną kryzysu w Grecji były mechanizmy działania strefy euro, które pozwoliły Grecji funkcjonować w taki sposób, w jaki nie mógłby żaden inny kraj działający poza strefą. Grecja zapewne oczekiwała, że jako nisko konkurencyjna gospodarka peryferyjna, o istotnym położeniu geopolitycznym, zawsze będzie korzystała z transferów finansowych. Analizując dane, trudno jednak zrozumieć, jak władze Grecji mogły doprowadzić gospodarkę do takiego stanu, że obecnie jedyną perspektywą na przyszłość tego kraju są kolejne pakiety pomocowe i oczekiwanie na redukcję zadłużenia. Co ważne - w Grecji ziścił się najgorszy scenariusz, koszty przyjęcia euro przeważyły nad korzyściami płynącymi z tytułu posiadania wspólnej waluty. Ta sytuacja spowodowała weryfikację optymistycznego podejścia innych krajów odnośnie do potencjalnego członkostwa w strefie euro (Bilski, Janicka, 2015).

Analiza wskaźników charakteryzujących grecką gospodarkę (por. tabela 1) nie pozostawia wątpliwości, że przed wybuchem kryzysu kształtowały się one w wyjątkowo niekorzystny sposób. W 2007 roku oszczędności/PKB pozostawały na bardzo niskim poziomie w stosunku do inwestycji/PKB (różnica 14 punktów procentowych!), co znalazło odzwierciedlenie w niespotykanej wartości deficytu na rachunku obrotów bieżących w odniesieniu do PKB. Kraj, który miałby taki deficyt i własną walutę dawno zostałby zdyscyplinowany przez międzynarodowe rynki finansowe i zmuszony do redukcji tego deficytu, bądź doświadczyłby wybuchu kryzysu walutowego, który skutkowałby m.in. deprecjacją waluty krajowej. Podobnie sytuacja wyglądała w odniesieniu do deficytu budżetowego i zadłużenia publicznego - ich wartości/PKB także znacząco przekroczyły dopuszczalne pułapy. Można powiedzieć, że gospodarka

${ }^{5}$ To doskonale widać na przykładzie oprocentowania obligacji skarbowych określanego przez warunki rynkowe. 
grecka już przed kryzysem funkcjonowała w oparciu o kredyt i to przede wszystkim zagraniczny. Należy podkreślić, że użycie pojęcia „funkcjonowała” nie jest przypadkowe, trudno bowiem mówić o rozwoju gospodarczym w sytuacji, gdy produkcja przemysłowa została w przeważającej części wygaszona, produkcja rolna - znacząco ograniczona, a sektor usług sprowadzony praktycznie do dwóch kategorii - transportu i turystyki.

Tabela 1

Wybrane wskaźniki makroekonomiczne w Grecji, lata 2007-2014

\begin{tabular}{||l|r|c|r|r|r|r|r|r||}
\hline \multicolumn{1}{|c|}{ Wyszczególnienie } & \multicolumn{1}{c|}{$\mathbf{2 0 0 7}$} & $\mathbf{2 0 0 8}$ & $\mathbf{2 0 0 9}$ & $\mathbf{2 0 1 0}$ & $\mathbf{2 0 1 1}$ & $\mathbf{2 0 1 2}$ & $\mathbf{2 0 1 3}$ & $\mathbf{2 0 1 4}$ \\
\hline PKB, ceny stałe (\%) & 3,538 & $-0,444$ & $-4,395$ & $-5,449$ & $-8,864$ & $-6,572$ & $-3,895$ & 0,774 \\
\hline Inwestycje (\% PKB) & 26,604 & 24,716 & 18,312 & 16,918 & 15,804 & 13,965 & 11,766 & 10,575 \\
\hline Oszczędności (\% PKB) & 12,613 & 10,247 & 7,424 & 6,813 & 5,907 & 11,491 & 12,348 & 11,500 \\
\hline Bezrobocie (\%) & 8,397 & 7,759 & 9,616 & 12,713 & 17,864 & 24,439 & 27,466 & 26,491 \\
\hline $\begin{array}{l}\text { Deficyt budżetowy } \\
\text { (\% PKB) }\end{array}$ & $-6,720$ & $-9,905$ & $-15,246$ & $-11,068$ & $-10,123$ & $-6,320$ & $-2,812$ & $-2,702$ \\
\hline $\begin{array}{l}\text { Zadłużenie publiczne } \\
\text { (\% PKB) }\end{array}$ & 102,778 & 108,752 & 126,220 & 145,668 & 170,96 & 156,494 & 174,948 & 177,188 \\
\hline $\begin{array}{l}\text { Saldo bilansu obrotów } \\
\text { bieżących (\% PKB) }\end{array}$ & $-13,992$ & $-14,469$ & $-10,888$ & $-10,105$ & $-9,897$ & $-2,473$ & 0,582 & 0,925 \\
\hline
\end{tabular}

Źródło: Opracowanie własne na podstawie danych: www.imf.org; http://www.bankofgreece.gr/Pages/en/ Statistics/rates_markets/default.aspx.

Swoboda przepływu kapitału i relatywnie niskie stopy procentowe umożliwiły Grecji zadłużenie się na rynkach zagranicznych na niespotykaną dotąd skalę, niemniej jednak z uwagi na fakt, że znacząca część napływającego kapitału klasyfikowana była jako przepływy wewnątrzstrefowe, ani strefa euro, ani sama Grecja nie była skalą tego zadłużenia specjalnie zaniepokojona. Należy w tym miejscu zdecydowanie podkreślić, że równowaga zewnętrzna postrzegana jako brak nadmiernego deficytu bądź nadmiernej nadwyżki na rachunku obrotów bieżących nie była przez UE włączona do kryteriów konwergencji, kraje strefy euro nie były także w żaden sposób dyscyplinowane do zredukowania ich nadmiernie wysokich wartości. Kwestia równowagi zewnętrznej stała się przedmiotem troski UE dopiero w $2011^{6}$, a więc zdecydowanie za późno.

\section{Podsumowanie}

Przed rokiem 2008 strefa euro postrzegana była jako sukces europejskiej integracji, głosy krytyczne były nieliczne i słabo słyszalne. Sytuacja uległa zasadniczej zmianie po wybuchu kryzysu, kiedy zaczęła przeważać retoryka krytyczna, a w krajach mają-

${ }^{6} 16$ listopada 2011 roku przejęte zostało Rozporządzenie Parlamentu Europejskiego i Rady (UE) Nr 1176/2011 w sprawie zapobiegania zakłóceniom równowagi makroekonomicznej i ich korygowania (Regulation (EU) No. 1176/2011 of the European Parliament and of the Council of 16 November 2011). 
cych perspektywę przystąpienia do strefy euro pojawiło się, nieobecne dotąd w szerszym wymiarze, podejście zdecydowanie eurosceptyczne. Przykład Grecji uświadomił krajom przygotowującym się do przyjęcia euro, że utrata niezależności prowadzenia polityki gospodarczej w kluczowych aspektach - pieniężnym, kursowym i de facto fiskalnym, bez żadnego równoważącego tę stratę mechanizmu odzyskiwania równowagi wewnętrznej i zewnętrznej, jest dla gospodarek krajowych, szczególnie krajów znajdujących się na niższym poziomie rozwoju gospodarczego, ogromnie ryzykowna. Kraje tworzące strefę euro cechuje różny poziom rozwoju gospodarczego i zapewne różnice te nie zostaną szybko zniwelowane, jeśli w ogóle kiedykolwiek to nastąpi. Nie wszystkie kraje są i będą w stanie implementować model działania gospodarki niemieckiej czy innych gospodarek krajów Północy. Nie wszystkie są w stanie osiągnąć ich standardy i poziom innowacyjności. Także w USA nie wszystkie stany mają swoje Doliny Krzemowe, niektóre mają pola uprawne, inne centra finansowe itd. To zróżnicowanie jest naturalne dla każdej struktury gospodarczej, a dla dużej struktury w szczególności. Na skutek przynależności do obszaru jednowalutowego Grecja nie stanie się Francją, a Włochy Niemcami. Kryzys w strefie euro nie tylko dowiódł, że mechanizmy działania strefy są wadliwe, to akurat można zmienić, ale że kraje tworzące strefę mają poważny problem z identyfikacją swojego miejsca i roli w jednoczącej się Europie. Strefa euro może więc pogrążyć się w stagnacji będącej pochodną nie tyle czynników gospodarczych, co społecznych i politycznych, choć zapewne historia gospodarcza odnotuje kwestie gospodarcze jako kluczowe dla spowolnienia procesów integracyjnych w UE na początku XXI wieku.

\section{Bibliografia}

Arghyrou M. G., Tsoukalas J. D. (2010), The Greek Debt Crisis: Likely Causes, Mechanics and Outcomes, „Cardiff Economics Working Papers”, nr 3, Cardiff Business School.

Beetsma R., Giuliodori M. (2010), The Macroeconomic Costs and Benefits of the EMU and Other Monetary Unions: An Overview of Recent Research, ,Journal of Economic Literature, American Economic Association", vol. 48 (3), ss. 603-641.

Bilski J. (2006), Międzynarodowy system walutowy, PWE, Warszawa.

Bilski J., Janicka M. (2015), Kryzys strefy euro. Przypadek Grecji, „Studia Prawno-Ekonomiczne”, nr XCVII, Łódzkie Towarzystwo Naukowe, Łódź, ss. 199-215.

Bordo M. D., Markiewicz A., Jonung L. (2011), Fiscal Union for the Euro: Some Lessons from History, ,NBER Working Paper”, nr 17380.

Bukowski S. I. (2007), Strefa euro, PWE, Warszawa.

de Grauwe P. (2003), Unia walutowa, PWE, Warszawa.

de Grauwe P. (2013), Design Failures in the Eurozone - can they be fixed?, European Commission Directorate-General for Economic and Financial Affairs, London School of Economics.

Delors J. (1989), Report on economic and monetary union in the European Community, Committee for the Economic and Monetary Union, presented April, 17, mimeo.

European Commission (1990), One Market, One Money: An Evaluation of the Potential Benefits and Costs of Forming an Economic and Monetary Union, „European Economy”, nr 44.

Gawlikowska-Hueckel K., Zielińska-Głębocka A. (2004), Integracja europejska. Od jednolitego rynku do unii walutowej, Wydawnictwo C.H. Beck, Warszawa. 
Geeroms H., Karbownik P. (2014), A Monetary Union Requires a Banking Union, Department of European Economic Studies, Bruges European Economic Policy Briefings 33 College of Europe.

Janicka M. (2010), Liberalizacja przepływów kapitałowych w gospodarce światowej. Przypadek Pol$s k i$, Wydawnictwo Uniwersytetu Łódzkiego, Łódź.

Janicka M. (2015a), Nierównowaga zewnętrzna w krajach strefy euro, „Acta Universitatis Lodziensis, Folia Oeconomica", nr 5 (316), ss. 99-111.

Janicka M. (2015b), Supervision on the EU Single Financial Market - attempt to reform, w: EMU - an Incomplete Project?, red. J. Bilski, E. Feder-Sempach, Difin, Warszawa, ss. 116-130.

Kouretas G. P., Vlamis P. (2010), The Greek Crisis: Causes and Implications, „Panoeconomicus”, nr 4, ss. 391-404.

Majone G. (2012), Rethinking European Integration after Debt Crisis, „Working Paper”, nr 3, The European Institute, London's Global University, London.

Meltzer A. H. (1996), Monetary Union: Benefits, Costs and a Better Alternative, Research Showcase (a) CMU, Tepper School of Business, Carnegie Mellon University.

Molle W. (2000), Ekonomika integracji europejskiej, Fundacja Gospodarcza, Gdańsk.

NBP (2014), Ekonomiczne wyzwania integracji Polski ze strefa euro, raport, www.nbp.pl.

Petrakos G. (2014), Economic Crisis in Greece. European and Domestic Market and Policy Failures, „Région et Développement”, nr 39, http://region-developpement.univ-tln.fr/fr/pdf/ R39/1-Petrakos.pdf.

Sicilia J., de Lis S. F., Rubio A. (2013), Banking Union: integrating components and complementary measures, „BBVA Research Working Paper”, nr 13/28, Madrid.

The Economist (2011), America's fiscal union. The red and the black, www.economist.com/blogs/ dailychart/2011/08/americas-fiscal-union? fsrc=rss.

Trzcińska A. (2013), Europejski Mechanizm Stabilności jako stabilizator w planowanej unii finansowej, „Materiały i Studia NBP”, nr 292, Warszawa.

Zielińska K. (2016), Financial Stability In The Eurozone, „Comparative Economic Research”, vol. 10, nr 1, The Journal of University of Lodz, Łódź, ss. 157-177.

Zika J. (2006), Costs and benefits of a monetary union, „Term Paper”, 2005/2006, European Economic Policies, IES FSV UK.

\section{Streszczenie}

Wzrost gospodarczy w strefie euro pozostaje na poziomie niższym od oczekiwanego, pomimo działań podejmowanych przez instytucje Unii Europejskiej i przez rządy państw członkowskich. Przyczyn obecnej sytuacji gospodarczej strefy euro należy poszukiwać jednak nie tylko wśród czynników ekonomicznych, ale także politycznych i społecznych. Przed rokiem 2008 strefa euro postrzegana była jako sukces europejskiej integracji, głosy krytyczne były nieliczne i słabo słyszalne. Sytuacja uległa zasadniczej zmianie po wybuchu kryzysu gospodarczego i finansowego. Kryzys w strefie euro nie tylko dowiódł, że mechanizmy działania strefy są wadliwe, ale również, że kraje tworzące strefę mają poważny problem z identyfikacją swojego miejsca i roli w jednoczącej się Europie. Celem artykułu jest charakterystyka i analiza mechanizmów działania strefy euro, które przyczyniły się do wybuchu kryzysu w strefie. Szczególna uwaga zostanie poświęcona kwestii swobody przepływu kapitału w kontekście prowadzonej przez EBC jednolitej polityki pieniężnej i braku wspólnej polityki fiskalnej.

Słowa kluczowe: strefa euro, integracja walutowa, kryzys gospodarczy i finansowy 


\title{
Mechanisms of the Euro area functioning and conditions of the financial crisis' outbreak in the zone
}

\begin{abstract}
Summary
Economic growth in the Euro area remains at the lower level than expected, despite the measures taken by the EU institutions and the national governments. The causes of the current economic situation in the Eurozone should be sought not only among the economic factors but also political and social ones. Prior to 2008, the Eurozone was seen as a success of the European integration, critical voices were few and difficult to hear. The situation changed dramatically after the outbreak of the economic and financial crisis. The crisis in the Eurozone not only proved that the mechanisms of the zone functioning are defective, but also that the countries forming the zone have a major problem with the identification of their place and role in the uniting Europe. This article aims to analyze the characteristics and mechanisms of the Eurozone functioning, which contributed to the outbreak of the crisis in the zone. Particular attention will be devoted to the free movement of capital in the context of the ECB's single monetary policy and the lack of a common fiscal policy.
\end{abstract}

Key words: Euro area, monetary integration, economic and financial crisis 
